\title{
Biodigital: set up of a digital collection to organize and facilitate the access to microscopical images and to produce education materials
}

Tania Araújo-Jorge ${ }^{1 *}$, Tânia S Cardona ${ }^{1}$, Bruno Ávila ${ }^{2}$, Lucia MB Gil ${ }^{1}$, Mauricio RMP Luz ${ }^{1}$, Daniel Benevides ${ }^{3}$, Paula Guarany ${ }^{3}$, Luiz Tucherman ${ }^{3}$ \& Helene S Barbosa ${ }^{2}$

${ }^{1}$ Education group, Lab Cell Biology, and ${ }^{2}$ Lab Cellular Ultrastructure, Dept of Ultrastructure \& Cell Biology, Instituto Oswaldo Cruz, Fiocruz, Rio de Janeiro, Brazil; ${ }^{3}$ Projeto Portinari (http://www.portinari.org.br). ;

*e-mail: taniaaj@ioc.fiocruz.br

The advent of electronic imaging and the internet improved dramatically the ability to create, search, access, and archive digital imaging files. In the last decade, microscopy, pathology and radiology centers had to face a exponential growth of image volume, which represents a significant problem in terms of digitization, storage, and subsequent manipulation. The amount of original images produced in Microscopy Centers is enormous, but about less than $1 \%$ of them get published in academic production of papers, books and thesis. All the rest stay only in the archives. In 2002 the Department of Ultrastructure and Cell Biology of the Oswaldo Cruz Institute, a centenary institution of biomedical research on Latin America, completed 25 years, and the first generation of scientists who started this center will soon retire. We then set up a Digital Collection of Biological Image (Biodigital) of the department, aiming the computerization of the process of archive and manage of biological images, in order: 1) to preserve the memory of the morphological work which has been done all over these years, by digitalizing the negatives and describing the content of each relevant image that has been generated; 2) to computerize the access to this digital library by indexing its content and preparing a software and a web interface for users, both for the department and for the general public; 3) to generate a privileged site for teachers to find copyright-free microscopic images to use in the classroom; 4) to facilitate the education group of the department to create innovative education materials (games, models, activity sheets, etc.- see ref.1) based on research data; 5) to make available a locus where other research groups could converge and deposit their images (the external library in complement to the internal library), in a way to increase the diversity of the Digital Image Collection. No similar product is available in Portuguese, and few are available in other languages. The process of construction of the project was original by itself, since we based on the methodology and know-how of the Portinari Project, a Brazilian team that prepared an image/document database unique in the world that made available more than 5,000 art works and more than 25,000 of the painter Candido Portinari. In the first phase, a complete diagnosis of the state of the physical support of the images (20,000 negatives and 15,000 digital files) was performed. Criteria for selection and rules for image classification, conditions of use and copyright were defined, as well as a system of indexing the images from a controlled vocabulary (not a free text). Four components were integrated: an archive server, a database server, an optical disk library and a communication network. The software was set up on a PC-SQL-server basis (Microsof), which allowed a page content created dynamically, a secure environment, browser compatibility, fast and good database interfacing. The internal user interface for entering data in the Digital Collection was built and the researchers from the department provide images continuously. It previews integration of the images with documents (e.g. publications) and events (e.g. conferences, lectures) in which they appeared, constructing a whole context. In a second phase, the internet external user interface is under development focusing teachers and students as a target public. The third phase will be the expansion of the Collection with image depositing from other Brazilian and foreign institutions. We expect that virtual galleries will soon be available.

1-Araújo-Jorge TC et al (2002) Electron microscopy images as an interactive tool for cell biology modeling and education Microsc. Microanal. 8 (Suppl. 2), DOI 10.1017.S1431927602104430, 1570CD

Supported by: CNPq - Programa Sociedade da Informação/ProTeM , IOC/Fiocruz 


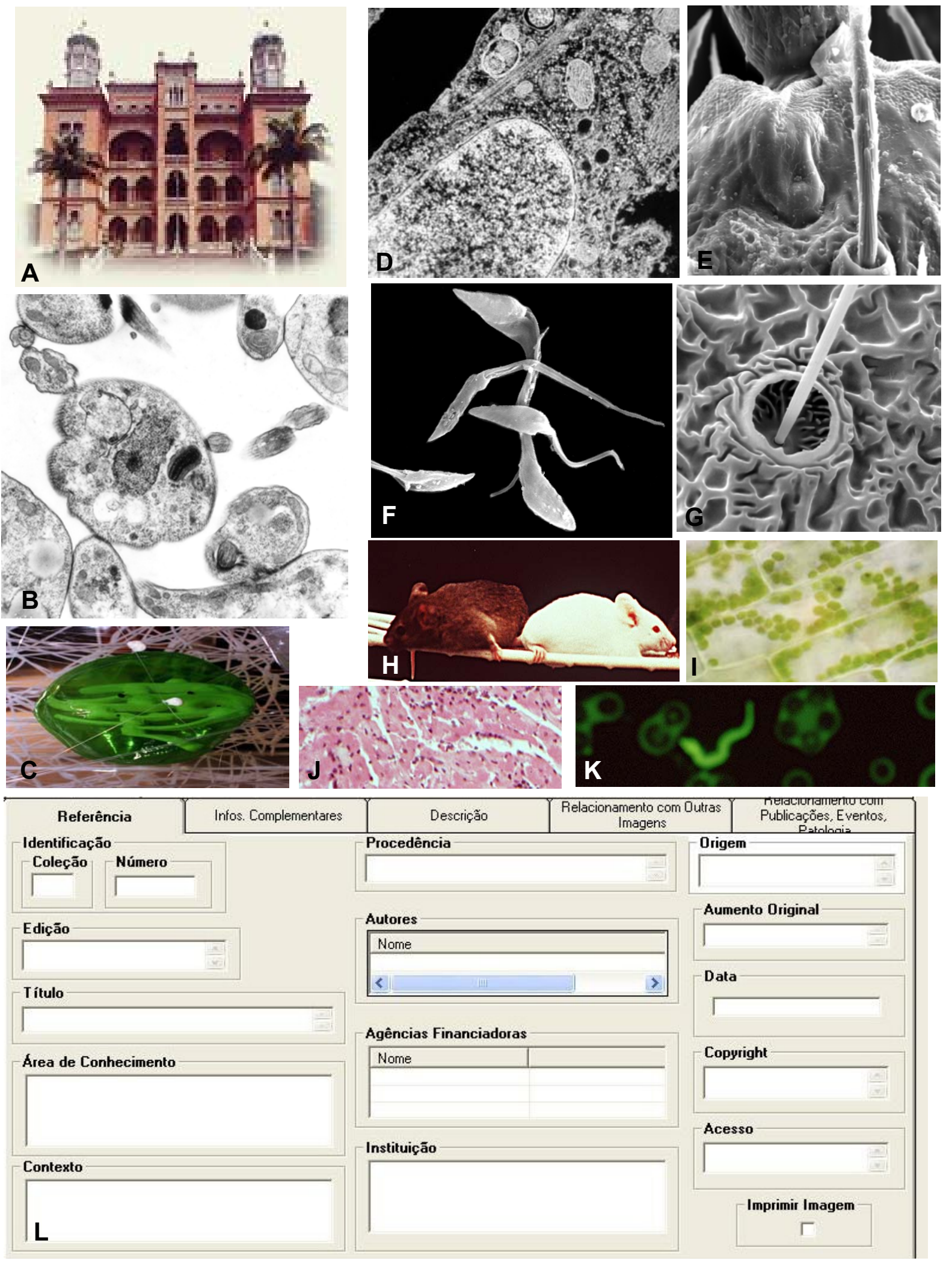

Examples of the diversity of biological images available in the BioDigital Collection: $A=$ Institutional images (e.g. Manguinhos castle); $\mathrm{B}, \mathrm{F}, \mathrm{K}$ : Trypanosomatidae protozoa $(\mathrm{B}=T$. verpertilionis (image number 1, 1977; $\mathrm{F}, \mathrm{K}=$ T. cruzi); $\mathrm{C}$ : cell models (chloroplast); $\mathrm{D}$, J: heart cells; E, G: antenna structures of insects; $\mathrm{I}=$ plant cells; $\mathrm{L}=$ User interface for the entry of data in the BioDigital collection. 